\title{
Energy Sustainability Paradox: Exploring the Challenges and Opportunities of Solar LED Street Lights in Sokoto, Nigeria
}

\author{
Bello-Yusuf S. ${ }^{1, *}$ and Bello A. ${ }^{2}$ \\ ${ }^{1}$ Department of Electrical and Electronic Engineering, Faculty of Engineering, Ahmadu Bello University, Zaria, \\ Kaduna State, Nigeria \\ ${ }^{2}$ Department of Urban and Regional Planning, Faculty of Environmental Design, Ahmadu Bello University, \\ Zaria, Kaduna State, Nigeria \\ Corresponding Author: *sabelloyusuf@gmail.com
}

https://doi.org/10.36263/nijest.2020.02.0204

\begin{abstract}
Sustainability, quest for greener environment and energy/cost savings are some of the driving forces for the global push in utilizing renewable energy resources for powering street lights especially those located in densely populated areas. Photo-voltaic and LED technologies are considered by many as a match made in heaven as they are essential if not mandatory for achieving these goals. For 11 years (between 2007 and 2018), there has been a significant effort by Sokoto State Government to light up streets in the central part of the city using these two technologies. Using a descriptive approach, the paper established the status, challenges and opportunities associated with solar powered Light Emitting Diode (LED) street lights in Sokoto over the 11 years period. Out of 450 installed units in the city, only 25\% are functional at present. The number is also gradually diminishing. The technological, social and institutional challenges associated with managing LED street light devices in the city were equally discussed. Promises of the technology, climatic conditions of the city and current push for metropolitan security are among the potential drivers for continuous implementation of the technology in the city. However, while the available solar power in the city serves as a driving force, its association with higher temperatures makes equipment maintenance difficult thereby undermining sustainability.
\end{abstract}

Keywords: Sustainability, Solar energy, LED, Urban management, Renewable resources

\subsection{Introduction}

Street lighting or sometimes referred to as "roadway lighting" is an important safety component for streets and highways. Street lights can help identify a walk-way from a car zone or help drivers see their surroundings clearly (Goodwin, 2013). Street lighting can help communities create a safer environment for residents to live, play and travel (Harris, 2008; McMorran et al., 2016). In places where energy poverty is an issue (like in Sokoto city, north western Nigeria), well-designed street lighting system can be a very reliable source of lighting for street vendors at night, thereby bringing business opportunities by expanding the hours of market activities after dark (Szakonyi and Urpelainen, 2015). Exploring the opportunities and the contextual challenges of implementing such projects will add perspectives in the development of sustainable practices for the provision of efficient and effective urban services. This is the specific focus of this paper using Sokoto city as a case study.

\subsection{Why LED?}

Street lighting technologies are evolving rapidly that many alternatives are out there to choose from and studies are being carried out to know how these technologies affect our vision (our eyes and the way we see things in our surroundings) and how does one technology excel over another and to what extent (Van Bommel and Van den Beld, 2004; Bullough and Radetsky, 2013). The new technologies are gradually replacing the old ones due to the improved light quality, energy savings, cost savings, and the environmental friendliness associated with them (Bullough, 2012). Among the various lighting technologies available, Light Emitting Diode (LED) supersedes the others in all performance 
metrics. The superiority of LED is a fact that is currently been documented and the driving force for this continued interest in LED implementation for outdoor lighting in general, is the environmental safety, service safety and cost benefit associated with them and this accelerated adoption of LED focuses mainly towards decreasing cost and improving performance. In (Bullough and Radetsky, 2013) a comparative study on various lighting technologies is carried out and LED lamp was shown to exceed all other lighting technologies in all technical parameters and the comparatively low running/maintenance cost associated with LEDs can serve as a compensation for the high capital cost associated with them (McMorran et al., 2016). Though all the available lighting technologies suffer from emission of some sort, researchers have shown that LED technology is by far the greenest of all (Mark, 2015). The number of street lights around the world is expected to hit 350 million by 2025, so in order to reduce the greenhouse gas emission to the lowest possible level, regulatory bodies and financial institutions must make sure that all new street lighting technologies are LED. One of the most impactful and readily implementable options available to cities is the replacement of less efficient outdoor street lighting with LEDs. The state-of-the-art LED-based street lighting technologies are efficient and able to provide savings of 50-70\% (Mark, 2015).

\subsection{Why Solar?}

Electrical energy may be the cleanest form of energy and the most secure if properly maintained and controlled, but one of the issues concerning electrical energy is that it is never there, it must be extracted from somewhere (wind, solar, hydro, thermal, coal, nuclear, bio-mass, etc.). These sources are mainly categorized into renewable and non-renewable sources (Wadi et al., 2018; Huai and Akasah, 2019). Though electrical energy is clean, the same cannot be said about the sources or the processes through which electricity is extracted from them. The renewables despite being seasonal and intermittent, tend to be more environment friendly and more abundant compared to their nonrenewable counter-parts (Wadi et al., 2018; Huai and Akasah, 2019). Solar and wind energy resources are the most abundant among the renewables and the higher level of intermittency and unpredictability in the wind energy systems make solar energy the most abundant and readily accessible among the renewables (Wadi et al., 2018). Solar and wind are sometimes used to complement each other (Wadi et al., 2018). The availability of solar energy and its green nature at the point of use coupled with unavailability of grid power in most developing countries make it a viable choice for powering street lights (Foster et al., 2009; Kumar et al., 2016; McMorran et al., 2016). Solar-LED street lights are considered by many to be critical components of smart cities (Sarkar et al., 2017; Sunehra and Rajasri, 2017; Mary et al., 2018; Shivaleelavathi et al., 2018).

Of the many ways to generate electricity only two are used to generate significant amount of power (Twidell, 2006). The first is the conversion of mechanical power to electrical power through relative motion of conductor and a magnetic field (Twidell, 2006). The second is the photo-voltaic cell or "solar cell". The device produces electricity from solar radiation through photo-voltaic effect which was first discovered by Edmond Becquerel in 1839. More than hundred years later (1954) Chapin, Fuller and Pearson used a doped semi-conductor silicon to develop a power source based on the photo-voltaic effect (Twidell, 2006). Despite taking more than a century from discovery to actual power production, photo-voltaic technology happened to be the fastest growing renewable energy technology in history (Zobaa and Bansal, 2011). This rapid growth of the technology was mainly due to the increasing demand for PVs, which has been driven by the following factors (Zobaa and Bansal, 2011).

- PVs are modular. Their capacity can thus be extended at any given time and at will

- They can be used as a stand-alone or centralized power source

- With the advances in power electronics, they can easily be linked with the utility grid.

- They are reliable and easy to use

- They have no moving parts and therefore free from noise

- They are emission free (at the point of use)

- With the advances in the technology the cost per unit energy produced is gradually going down.

\subsection{The P-N Junction Diode}

It is important to note that photo-voltaic cells and LEDs work on the same principle of p-n junction diode. Therefore, to understand these two technologies one needs to understand the working principle 
of p-n junction diode. When light energy is used to initiate the movement of charge carriers in a semiconductor material, the material is acting as a PV cell, and when electrical energy is used to produce light from a semiconductor material it is said to be acting as an LED.

Semiconductors are mostly metallic elements found in group 4 of the periodic table, these elements have electrical properties somewhere between that of a good insulator and a good conductor at room temperature. There resistivity is high near absolute zero and the conductivity increases with increase in temperature, meaning that they have a negative temperature coefficient. These elements are combined with group 3 and group 5 element (impurities) in a process called doping to form a p-type or n-type semiconductors respectively. A p-type and an n-type semiconductor when joined together form a p-n junction diode. In a doped semiconductor material, the charge carriers can either be electrons or holes. The majority carriers in an n-type semiconductor are the electrons.

\subsubsection{Photo-electric or photo-voltaic effect}

Photo-voltaic generation will occur in a material when the material absorbed light in the form of an electromagnetic radiation causing separation of positive and negative charge carriers in the material. In the presence of an electric field (Zobaa and Bansal, 2011), these charge carriers can produce a flow of current when connected to an external circuit. In general PV generation can be summarized into three physical processes.

- Light absorption

- Charge excitation/separation

- Voltage creation or charge collection

Figures 1 and 2 illustrate these processes.



Figure 1: Illustrating the physical processes in a PV cell



Figure 2: Showing the main components of a photo-voltaic cell and the physical processes involved (Source: ocw.mit.edu)

The main indication of failure in a PV cell is a reduction in their power output as a result of drop in their efficiency. This mainly happens when the PV array is not receiving enough light energy due to a shading, accumulation of dust on the PV panel or when the PV is operating in harsh weather conditions (extreme heat and wind) (Kama et al., 2017). According to (Kama et al., 2017) deposits on the solar panel can cause up to $68 \%$ drop in efficiency.

\subsubsection{Light Emitting Diode (LED)}

LED is a special form of PN junction diode that produces light when electric current pass through them. This happens when an electron combines with a hole inside the junction. Because the electron is at higher energy level than the hole, the electron has to lose some amount of energy in order to be combined with a hole (Branas et al., 2013). This energy is released as a form of light, the color as well as the amount of light output depends on the intensity of such collisions and the temperature of the junction (Narendran and Liu, 2015). Figure 3 illustrates how light is generated when a current passes through LED. 


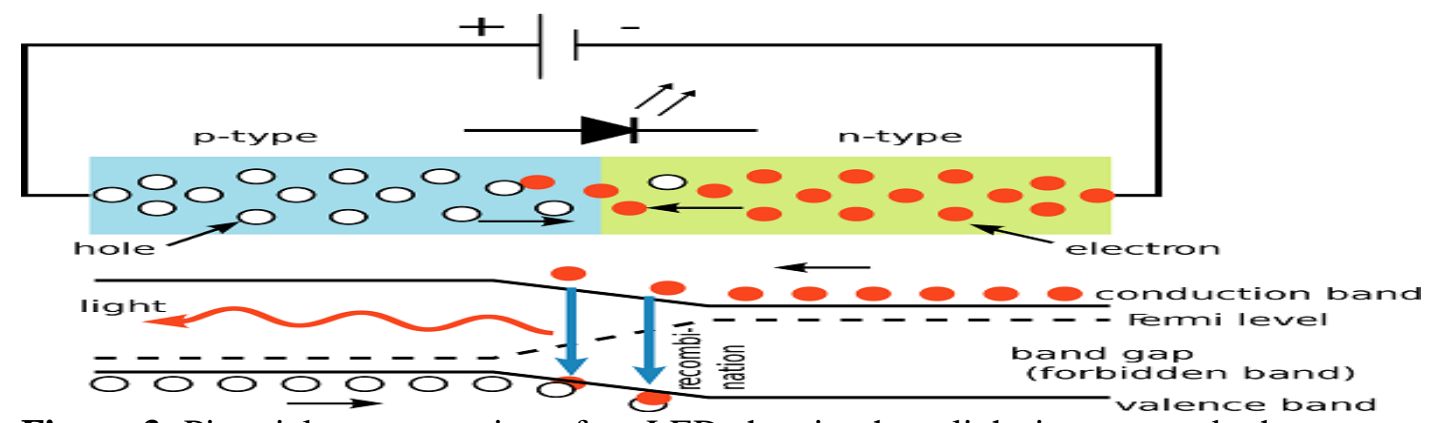

Figure 3: Pictorial representation of an LED showing how light is generated when current is passed through it

The lifetime and the output power of high output LED like the ones used for street and outdoor lightings, is a function of the junction temperature (Narendran and Liu, 2015). The junction refers to the point inside the LED where light generation takes place and also the point of heat generation, both heat and light output increase with increase in the input current (Narendran and Liu, 2015). It is important to note that LED system is not a one component system but comprises many components which include LED array, mechanical housing, printed Circuit Board (PCB), electrical connectors, electronic drivers, heat sink and Optical system. Failure of one or more of the above components may if not attended to in time lead to complete system failure. LED light sources do not fail instantaneously; the failure is normally seen as a reduction in light output commonly referred to as "lumen depreciation". The lifetime of an LED is usually expressed using percent lumen depreciation and percent lumen maintenance. According to (Narendran and Liu, 2015) light running at room temperature is supposed to have a lumen maintenance of $70 \%$ after 100,000 hours of service life.

\subsection{Challenges associated with LEDs and PVs}

Some of the challenges already highlighted in literatures associated with LED/PVs include the following:

- The uncertainty in the technology. Most people consider LED and PV technology to be unproven, and this bring about the question "whether now" (Arnold et al., 2012). The fact that LED and PV technology are rapidly growing is one of the reasons some people go for them, and at the same time it makes some people to wonder whether the time is right to move for LED or PV for street lighting or wait till later in the future considering the reliability uncertainties and future potential gain they may get, when better products are produce and became available in the market. LED have a lifetime of almost 15 years in theory, but currently there is no LED project that lasted for that amount of time because, the old ones are being replaced whenever better ones became available in the market (Arnold et al., 2012).

- High initial cost. The high initial cost associated with LED and PV and their cost effectiveness have direct impact on value to consumers. This high initial cost is also a reason for the "whether now" question, as the cost of LED is rapidly going down and the efficiency of PV is gradually going up (Arnold et al., 2012; Bullough, 2012; Kumar et al., 2016; Rajab et al., 2017).

- Removing a street light before the end of its useful life is a risk that will always come with a cost which utility providers may not be willing to account for (Mark, 2015).

In most of the researches being carried out in LED technology, one of the main objectives is reducing energy consumption without sacrificing light output, therefore the revenue gotten from LED may probably be lower than that obtainable from other lighting technologies for the same purpose. This can also make institutions reluctant in implementing LED for street lighting (Arnold et al., 2012).

\subsection{Methodology}

This is a time-series study of street lighting infrastructure installed in the city of Sokoto over a period of 11 years (between 2007 and 2018). The approach involves providing a theoretical base in which the incentives for adoption of renewable and less environmentally violent sources of energy for urban street lighting is stressed. 
The study utilised both primary and secondary data sources. In addition to such meteorological data as temperature and solar radiation, data is collected on the status and maintenance challenges across the 450 installed units in the city. The units are purposively sampled as only solar powered LEDs are considered in the study. A checklist method is used to characterise the units across all the affected streets (see Figure 10) in the city. Indices used include battery/panel sizes, lamp wattage and percentage of units that are functional at the time of data collection. Through an informal interview with one of the contractors we were able to establish the optimal sizing of battery energy storage system (BESS) and PV panel for a given LED lamp size, optimal location and placement of the panels and the type of maintenance to carry out on the street lights and how often? The discussion on the city-specific challenges adopted three key factors. They are technical, social and institutional.

\subsection{Results and Discussion}

\subsection{Area under study}

The city of Sokoto is as illustrated in Figure 4.

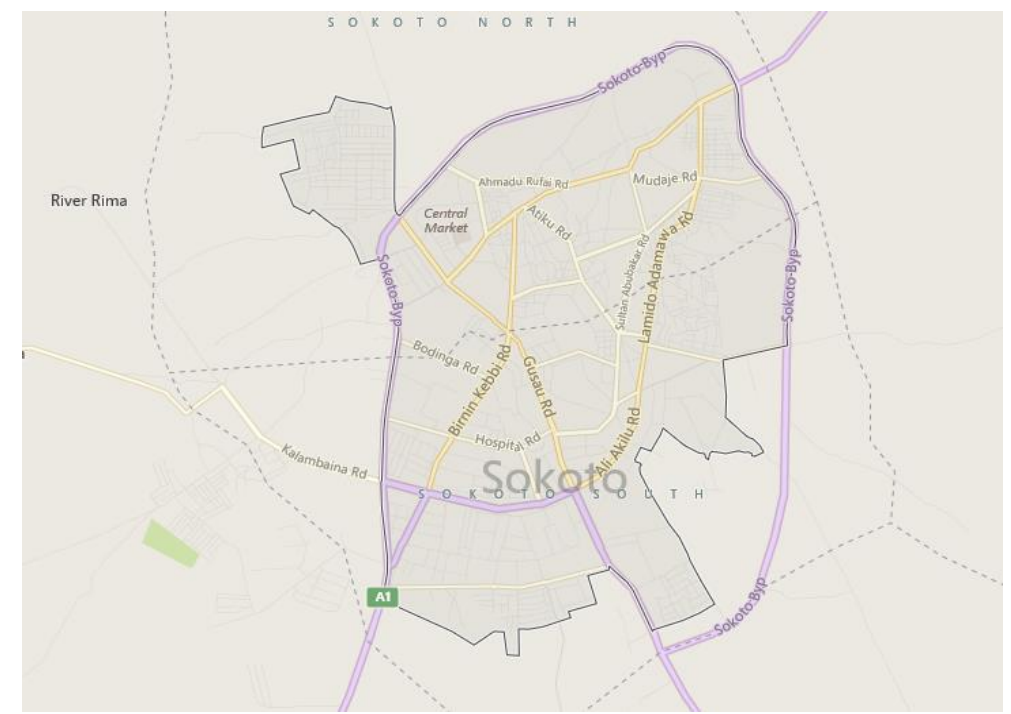

Figure 4: Sokoto city road map

(Source: Google maps)

Sokoto is the capital city of Sokoto state located in the north western part of Nigeria between latitudes $12^{\circ} 57^{\prime} 25.65^{\prime \prime} \mathrm{N}$ to $13^{\circ} 6^{\prime} 5.51^{\prime \prime} \mathrm{N}$ and longitudes $5^{\circ} 17^{\prime} 8.44^{\prime \prime} \mathrm{E}$ to $5^{\circ} 11^{\prime} 1.74 " \mathrm{E}$. The city is situated on A1 highway that connects to Niger Republic through Illela. The city is on an elevation of about $218 \mathrm{~m}$ above sea level. Nigeria is one of the African countries with great solar potential and that potential is much higher in the northern region especially in the far north where the city is located.

Sokoto is one of the cities with the highest solar potential in the region and this is strongly connected to its semi-arid tropical location. The city has an average annual temperature of about $28.3^{\circ} \mathrm{C}$. While the maximum daytime temperatures peaks is at $40^{\circ} \mathrm{C}$. In the warmest months of March to May, the temperatures may reach up to $45^{\circ} \mathrm{C}$. This means that the solar energy and photovoltaic potentials of the city are among the key natural potentials for solar powered installations. This is depicted in Figures 5-8. As much as the high intensities from solar radiation are positive potentials for solar energy harvest, they are equally threatening the management of such devices. 


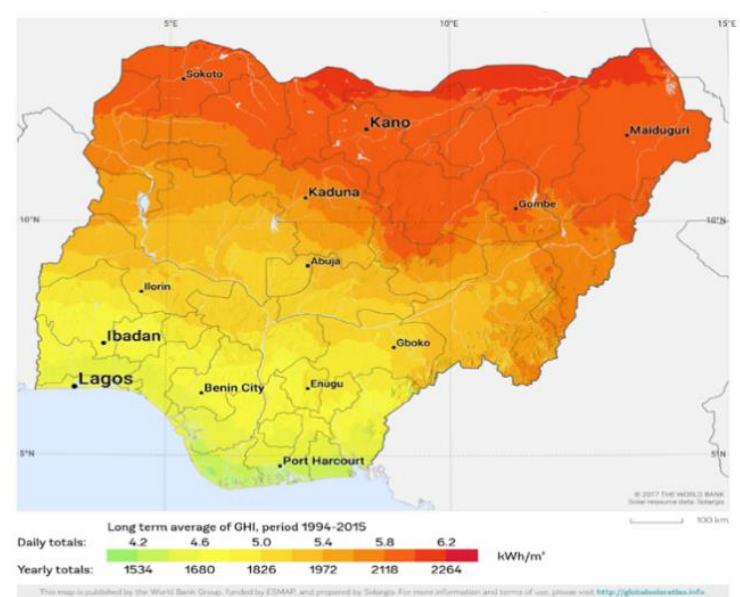

Figure 5: Solar energy potential in Sokoto

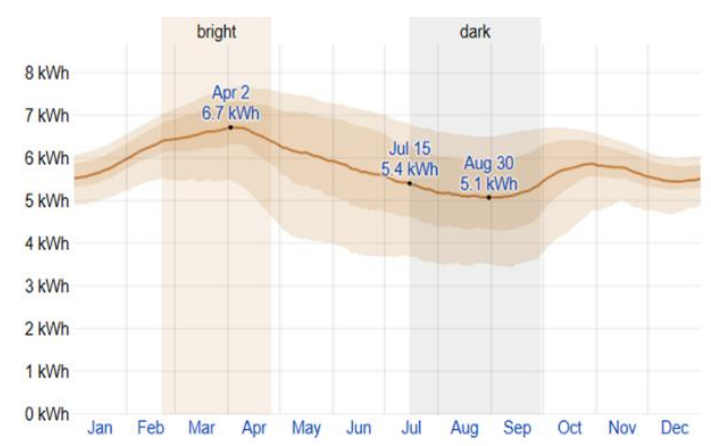

Figure 7: Average Solar irradiation in Sokoto

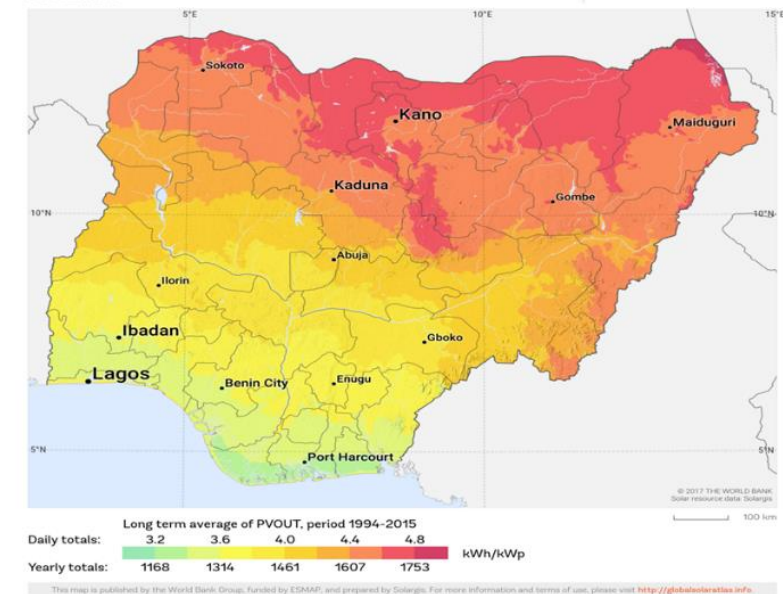

Figure 6: PV potential in Nigeria

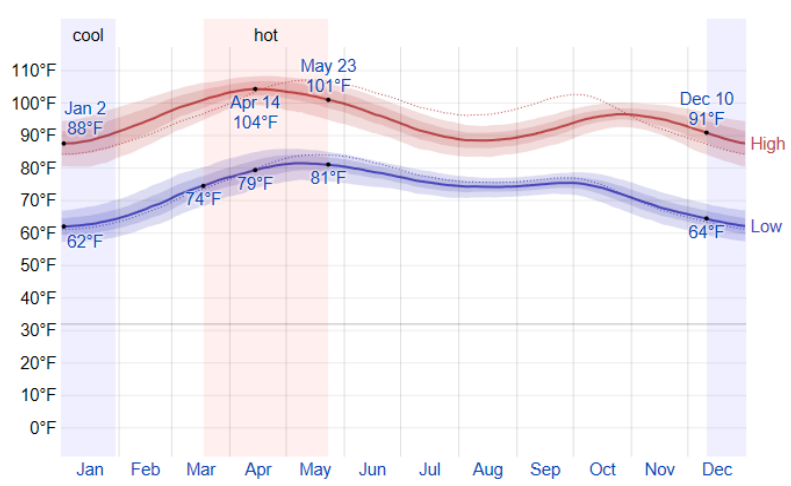

Figure 8: Monthly temperature averages for Sokoto

\subsection{Electrical energy in Sokoto}

Electrical energy in Sokoto is mostly supplied via the following sources: utility grid, diesel generators, off-grid solar (stand-alone and centralized) and a very small amount supplied by wind turbines. For industrial customers, the energy is supplied by the utility grid and diesel generators. Solar whether stand-alone or centralized, is yet to be used for industrial purposes. Residential customers (street vendors included) get their supply from utility grid, diesel generators and off-grid solar (stand-alone). Centralized solar and a very small amount of wind are used to supply remote areas that have no access to the utility grid. The oldest known (documented in this paper) form of street lighting system in Sokoto was supplied from the utility grid but this has not been a common practice in recent years. Existing street lighting projects are mainly supplied by stand-alone solar system and diesel generators. The electrical energy supply from the utility grid can only serve 55\% of the total energy demand at a time and so the city suffers from an unpredictable load shedding and forced outages at times.

The average energy consumption may be around $42 \mathrm{MWh}$ which can get to a peak value of $55 \mathrm{MWh}$ at night as residential customers and a significant number of street vendors mainly use the energy for lighting. The peak value can even go higher during hot season when the surrounding temperature reaches $38-45^{\circ} \mathrm{C}$ as shown in Figure 8. During this time significant amount of energy is used for cooling (air conditioning). This happens through the months of April-May and even some days in October. As a result of this there is a higher stress on the distribution grid, consequently the transformers, the feeders and other components heat up. The surrounding temperature add to the heat generated in the equipment during that period of the year and this result in the availability and reliability of the distribution system been comprised. As a result, the overall system capacity is significantly reduced. 


\subsection{Street lighting in Sokoto}

Street lighting is a common practice in the city of Sokoto for almost 40 years, though it was mainly for security reasons as there were no much transportation facilities back then. The earliest form of street lighting system we came across was in the form of lamp mounted at a height of $4 \mathrm{~m}$ above the ground on a $6 \mathrm{~m}$ electric pole (utility grid) and powered from the grid. The type of lamp used is a fluorescent lamp enclosed in a glass casing (Figure 9). The project completely failed after some years due to lack of maintenance resulting largely from little or no commitment to the project from the public institutions responsible. Remnants of such projects can still be cited across the city. Other forms of street lighting were used subsequently (not documented here) especially those with dedicated pole, and the fluorescent lamp in the earlier set-up were replaced with halogen lamps. The source of power remains the same, "the utility grid". In early 2004 there is greater need for street lighting in Sokoto due to security issues especially in the central part of the city.

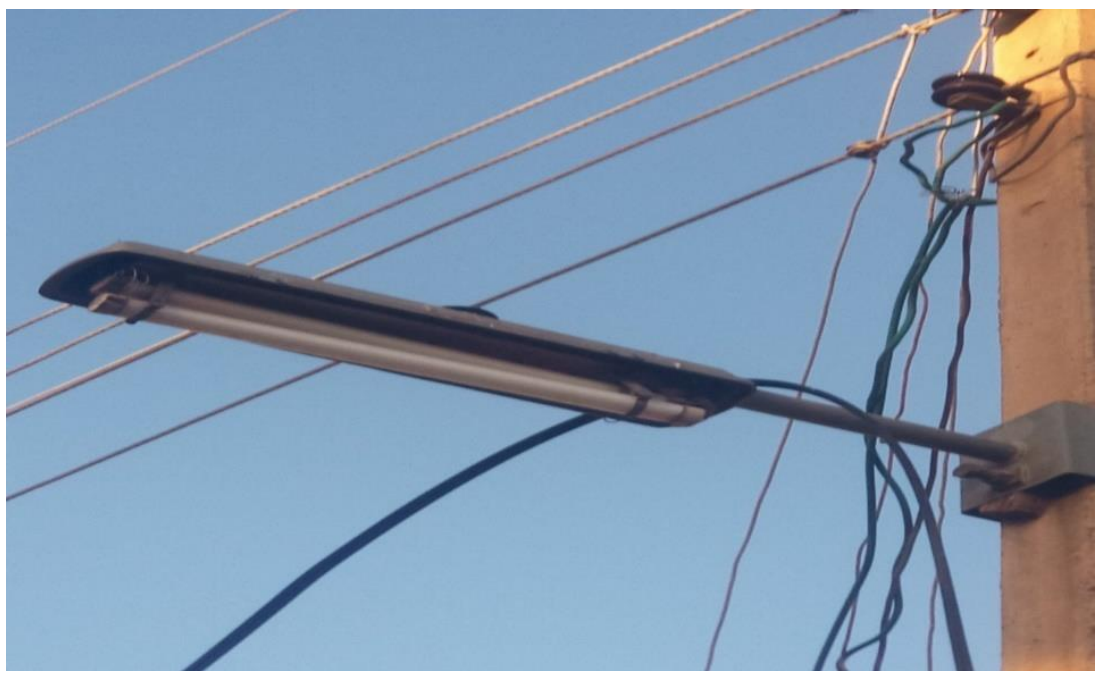

Figure 9: The earliest (documented in this paper) form of Street light in Sokoto. The fluorescent lamp is protected in a glass casing, which in this case is broken

\subsubsection{Solar-LED Street Lights in Sokoto metropolis}

The spatial distribution of the 450 installed units of solar LEDs in Sokoto metropolis is shown in Figure 10. As demonstrated in the figure, one can observe the fact that the projects are all in the "inner city" cordoned by the eastern and western bye passes.

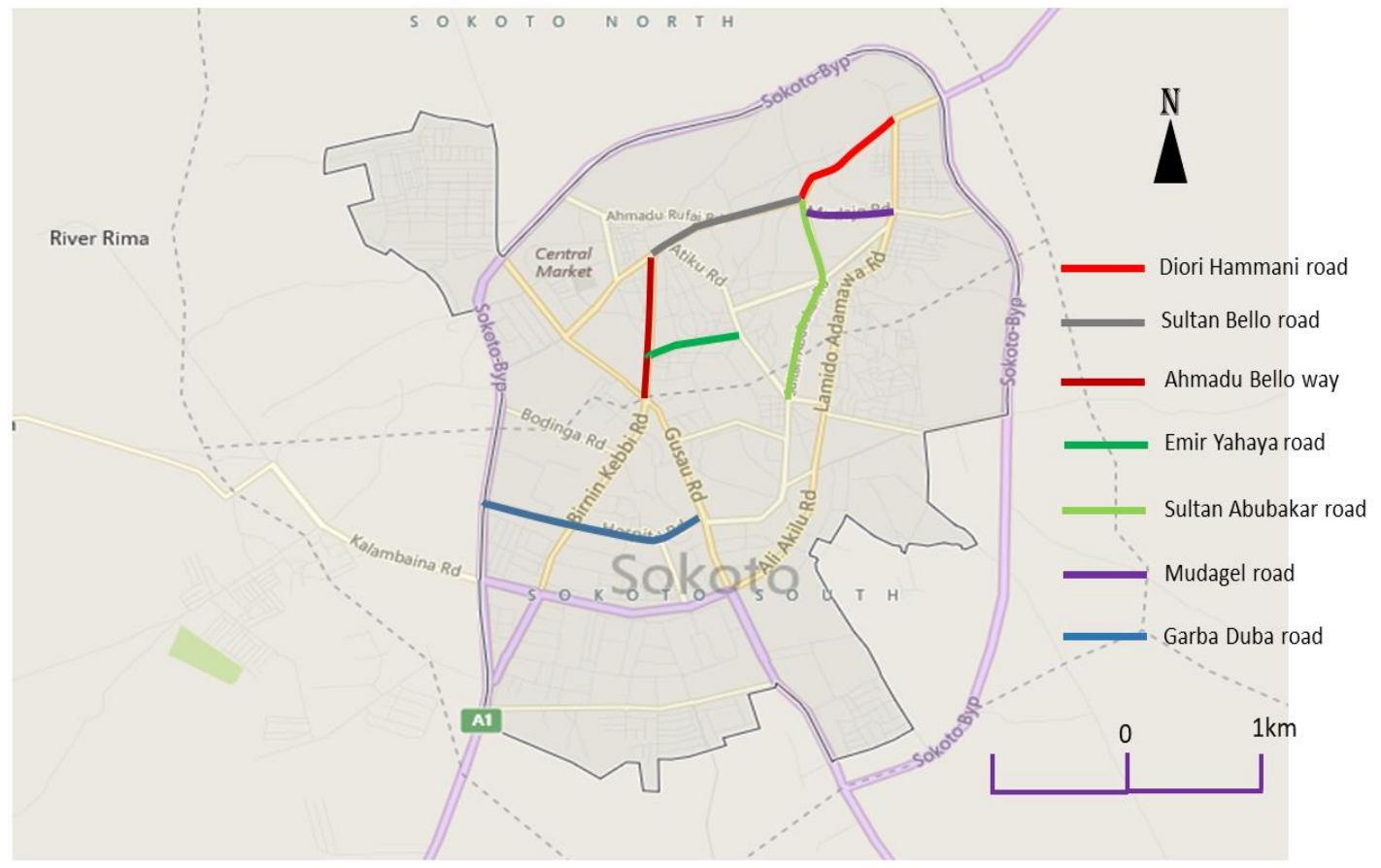

Figure 10: Map of Sokoto city - showing the streets under study 
The use of solar energy for street lighting started later in the year 2009. The driving forces for this implementation are:

- Environmental concerns (GHG and Sustainability of resources)

- Paucity of electricity

- Availability of renewable (Solar and Wind).

The high capital cost associated with implementing solar power increases with increase in energy requirement of the load, therefore the regulatory bodies had to look for the most efficient way to power those lights and it so happens that LED lights are the best candidates in that respect. The earliest ones documented in this work are those along Diori Hammani road, and those along Mudaggel road from 'Yar Iraki to Kofar Rini. The project failed due to poor project design. A much better approach was carried out when implementing those from Sultan Palace all the way to Maryam Abacha Women and Children Hospital and from Sultan Palace to Rijiyar Dorawa. This same configuration was also used for Ahmadu Bello way, Emir Yahaya road, Sultan Atiku road and from Gidan man Ada all the way to Round mai ruwa. This is illustrated in the Table 1.

Table 1: Installed Solar and LED Street lights in Sokoto metropolis

\begin{tabular}{|l|l|l|l|l|l|c|}
\hline Street name & $\begin{array}{l}\text { No. } \\
\text { fixtures }\end{array}$ & $\begin{array}{l}\text { Wattage of } \\
\text { lamp }\end{array}$ & Battery size & $\begin{array}{l}\text { Panel } \\
\text { size }\end{array}$ & $\%$ working & Challenges \\
\hline D/Hammani & 43 & $90 \mathrm{~W}$ & $150 \mathrm{AH}$ & $200 \mathrm{~W}$ & $0 \%$ & $\begin{array}{l}\text { Theft, poor design, } \\
\text { vandalism and } \\
\text { maintenance }\end{array}$ \\
\hline Maniru road & 38 & $90 \mathrm{~W}$ & $200 \mathrm{AH}$ & $200 \mathrm{~W}$ & $0 \%$ & $\checkmark$ \\
\hline Muddagel road & 39 & $120 \mathrm{~W}$ & $200 \mathrm{AH}$ & $300 \mathrm{~W}$ & $0 \%$ & $\checkmark$ \\
\hline A/Rufai road & 92 & $80 \mathrm{~W}$ & $300 \mathrm{AH}$ & $300 \mathrm{~W}$ & $10 \%$ & $\begin{array}{l}\text { Theft } \\
\text { maintenance }\end{array}$ \\
\hline E/Yahya road & 46 & $\checkmark$ & $300 \mathrm{AH}$ & $300 \mathrm{~W}$ & $7 \%$ & $\checkmark$ \\
\hline S/Atiku road & 52 & $\checkmark$ & $300 \mathrm{AH}$ & $300 \mathrm{~W}$ & $5 \%$ & $\checkmark$ \\
\hline A/Bello way & 48 & $\checkmark$ & $300 \mathrm{AH}$ & $300 \mathrm{~W}$ & $5 \%$ & $\checkmark$ \\
\hline $\begin{array}{l}\text { G/Duba road and } \\
\text { others }\end{array}$ & 142 & $\checkmark$ & $300 \mathrm{AH}$ & $300 \mathrm{~W}$ & $15 \%$ & Poor maintenance \\
\hline
\end{tabular}

The number of installed Solar-LED Street lights in Sokoto metropolis as at 2016 is 450, which is about $40 \%$ of the total installed street lights in the city. This number dropped to 370 when some of the projects failed and the PVs were replaced with diesel generators. Some of the installed solar-LED street lights are shown in Figures 11-13.



Figure 11: Street lighting project at Diori Hammani road. The project failed completely

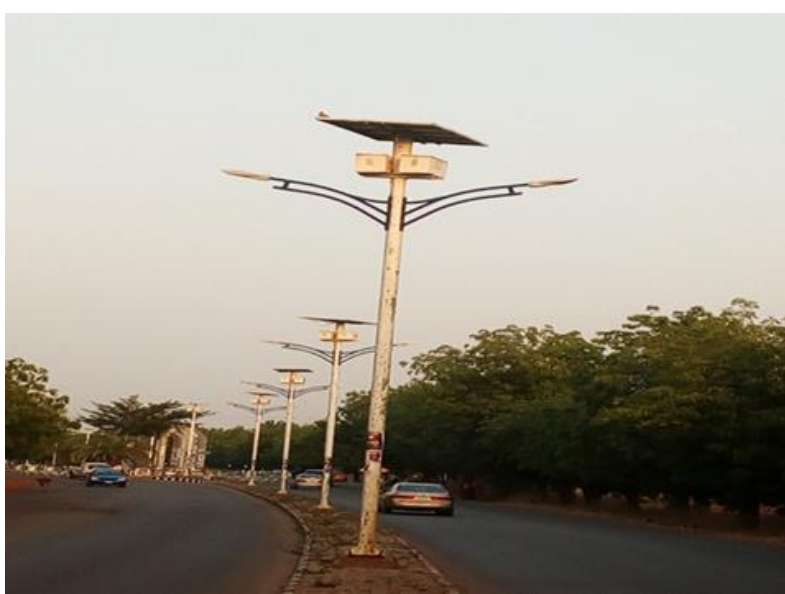

Figure 12: Street lighting project at Garba Duba road. The same configurations were used for other projects not shown 


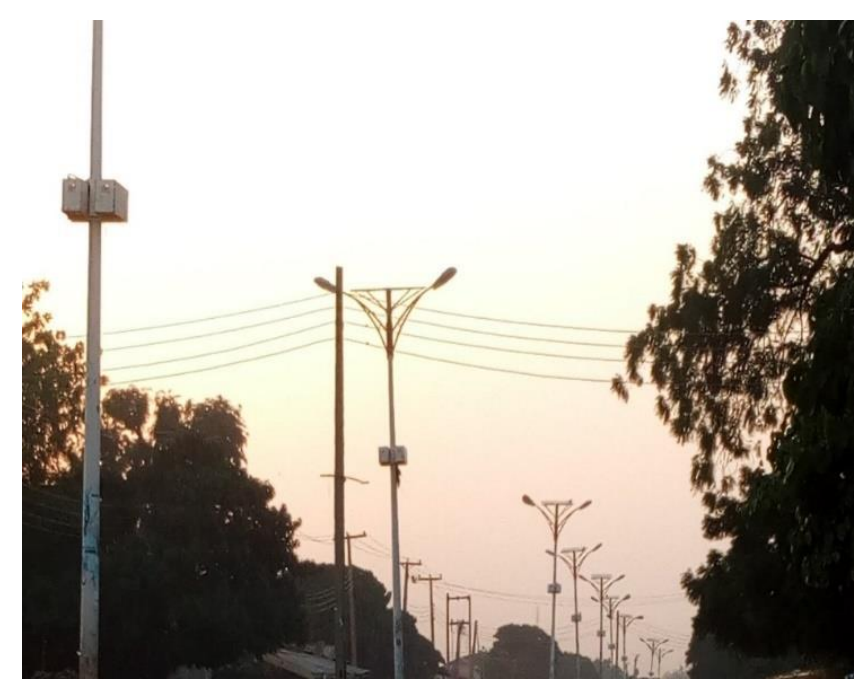

Figure 13: Street lighting project at Mudaggel road

\subsection{The challenges in Sokoto metropolis}

LED and PV technologies are very promising technologies that come with huge benefits, but due to a number of challenges in Sokoto metropolis these components are performing below expectation. These challenges are discussed under the three headings of technical, social and institutional.

Technical: The initial design in the first and second generation was not optimal because of poor project design as the PV capacity and that of the Battery cannot supply the system for a period of $12 \mathrm{hrs}$. One thing very important to note is that, the performance of any semiconductor material depends on its operating conditions like temperature (in the case of PVs) and the wind speed. The temperature in Sokoto is unfavorable to optimal performance of any electronic equipment even with the use of heat-sink. The batteries, the panels as well as the LED lamps are all exposed to a very harsh weather conditions which significantly affect their performance in a very negative way thereby reducing their efficiency and eventually rendering the overall system useless. Researches have shown that the rate at which heat losses increases in an LED is greater than the rate at which the light output increases with increase in current, and the efficiency of a PV and the lifetime of a battery drastically reduces at temperatures above $25^{\circ} \mathrm{C}$ (Foster et al., 2009).

Social: One of the major challenges to implementing Solar-LED Street lights in Sokoto metropolis is theft. The batteries and the charge controllers are stolen one after the other and since light is a threat to those responsible for this act, they initially make sure that the targeted area is in the dark using any form of vandalism. Since little or no effort is being made to bring the public in to the system, this make people to show a NIMBY (not in my backyard) attitude on the functioning or failure of these projects.

Institutional/Regulatory: All the street lights in Sokoto metropolis are provided and supposed to be managed by the government. The responsible authorities seem to exhibit very little or no commitment to the maintenance of these projects. A fault in the form of dimming in the light intensity or flickering may arise, as small as it looks if not checked and corrected the street light will completely fail eventually.

\subsection{Keys to moving forward}

Willingness: There are enough reasons to make an unwilling institution delay the implementation of the solar-LED system for street lighting, but if the institution is willing the advantages of adopting solar-LED street lights outweigh the reasons for stalling.

Warranty Lapses: The fact that up to this day no solar powered LED street lighting system has been in existence for more than the stated lifetime, does not mean they cannot. Because even if they could last for that amount of time, they are replaced with better ones in a shorter time due to the rapid development in these technologies. And more importantly, most of these products nowadays come with warranty (Arnold et al., 2012). 
The replacement is easy: LED and PVs are mostly modular and can easily be upgraded with replaceable module as the technology evolves.

In many of the researches carried out the energy savings and cost savings coupled with the need for a greener environment can serve as a compensation for the high capital cost in LED and PVs (Huai and Akasah, 2019; Kumar et al., 2016; McMorran et al., 2016; Rajab et al., 2017).

\subsection{Conclusions}

The fact that Solar-LED Street lights have a negligible maintenance cost doesn't mean they can perform optimally without any form of maintenance. Though the maintenance cost is small, not carrying out maintenance practices on these projects will cause them to fail completely. It is obvious that the government is interested in the implementation of PV and LEDs for street lighting due to the benefits associated with these technologies. In order to reap out these benefits, responsible institutions should establish a routine maintenance exercises for these projects ranging from cleaning the dust on the panels, checking the specific gravity of the batteries and the performance of charge controllers. Many low-quality PV and LED are out there in the market, the regulatory bodies should make sure that state of the art components are used in carrying out any new project or upgrading the existing ones, and that a good project design is carried out.

Even the best PVs, batteries and LEDs out there will suffer from the harsh weather in Sokoto. A proper form of protection should be given to system components against heat if they are to perform as expected. PVs and LEDs are designed to work in the range of $25-30^{\circ} \mathrm{C}$, but the temperature in Sokoto can go much higher than that for a significant amount of time (Figure 10). Such high temperatures are enough to compromise the performance of the street light components. LED lighting fixtures are usually sold with the heat sink attached. Yet, many manufacturers encourage providing them with additional protection when using them in a hostile environment. Although many of the projects carried out in Sokoto metropolis have failed, the percentage of those working perfectly in the metropolis and other parts of the world is a testimony that this type of Street lighting system has a very promising future. The optimism regarding the future promises of street lighting has earlier been emphasized by many (Arnold et al., 2012; Kumar et al., 2016; McMorran et al., 2016).

The maintenance of a stand-alone solar street lights is often more challenging than that of a centralized one due to the number of components involved (Kama et al., 2017). Street lighting providers should thus consider the implementation of a Centralized Solar Powered System (CSPS) if proven to be economically feasible.

\section{References}

Arnold, G., Mellinger, D., Markowitz, P., Burke, M. and Lahar, D. (2012). A Win-Win-Win for Municipal Street Lighting: Converting Two-Thirds of Vermont's Street Lights to LED by 2014. Proceedings of the 2012 ACEEE Summer Study on Energy Efficiency in Buildings, pp. 0193000144.

Branas, C., Azcondo, F. J. and Alonso, J. M. (2013). Solid-state lighting: A system review. IEEE Industrial Electronics Magazine, 7(4), pp. 6-14.

Bullough, J. (2012). New lighting technologies and roadway lighting: An informational brochure. BUREAU OF TRANSPORTATION STATISTICS U.S. Department of Transportation, pp. 1-6.

Bullough, J. D. and Radetsky, L. C. (2013). Analysis of new highway lighting technologies. National Cooperative Highway Research Program, pp. 4-7.

Foster, R., Ghassemi, M. and Cota, A. (2009). Solar energy: renewable energy and the environment: CRC Press.

Goodwin, M. (2013). Downtown Detroit Energy Efficient Street Lighting (No. 1962). Detroit Economic Growth Corp, Detroit, MI (United States), pp. 1-4. 
Harris, P. E. (2008). Solar street lights. U.S. Patent Application 11/523,540. https://patentimages.storage.googleapis.com/a3/8d/61/e0a2baf1dc9c72/US20080094818A1.pdf

Huai, L. P. and Akasah, Z. A. (2019). A Proposed Standard Design of Solar Street Light System Towards Energy Efficiency Development for Managing Facility Planning. In: 8th International Conference on Industrial Technology and Management (ICITM), March 2019, pp. 196-200, IEEE.

Kama, A., Diallo, M., Drame, M. S., Ndiaye, M. L., Ndiaye, A. and Ndiaye, P. A. (2017). Monitoring the performance of solar street lights in sahelian environment: Case study of Senegal. In: 10th International Conference on Developments in eSystems Engineering (DeSE), June 2017, pp. 56-61, IEEE.

Kumar, N. M., Singh, A. K., and Reddy, K. V. K. (2016). Fossil fuel to solar power: a sustainable technical design for street lighting in Fugar City, Nigeria. Procedia Computer Science, 93, pp. 956966.

Mark, K. (2015). The Big Switch: Why it's Time to Scale up Led Street Lighting. THE CLIMATE GROUP, pp. 1-9. Retrieved from London.

Mary, M. C. V. S., Devaraj, G. P., Theepak, T. A., Pushparaj, D. J. and Esther, J. M. (2018). Intelligent energy efficient street light controlling system based on iot for smart city. In: International Conference on Smart Systems and Inventive Technology (ICSSIT), December, 2018, pp. 551-554, IEEE.

McMorran, B. J., Adami-Sampson, N. D. and Bachman, N. C. (2016). Investigating Solar Street Lights in Mandi and Kamand. Worcester Polytechnic Institute, pp. 1-16.

Narendran, N. and Liu, Y. W. (2015): Invited Paper: LED Life versus LED System Life. In SID Symposium Digest of Technical Papers, 46(1), pp. 919-922.

Rajab, Z., Khalil, A., Amhamed, M. and Asheibi, A. (2017). Economic feasibility of solar powered street lighting system in Libya. In: 8th International Renewable Energy Congress (IREC), March, 2017, pp. 1-6, IEEE.

Sarkar, S., Mohan, K. and Vankhande, P. (2017). Smart street-lighting using green energy designing a novel stand-alone solar powered lighting system. In: International Conference on Intelligent Computing and Control Systems (ICICCS), June, 2017, pp. 157-163, IEEE.

Shivaleelavathi, B. G., Vinay, M. E. and Sucheeth, V. (2018). Solar Based Smart Street Lighting System. In: International Conference on Electrical, Electronics, Communication, Computer, and Optimization Techniques (ICEECCOT), December, 2018, pp. 1479-1483, IEEE.

Sunehra, D. and Rajasri, S. (2017). Automatic street light control system using wireless sensor networks. In: IEEE International Conference on Power, Control, Signals and Instrumentation Engineering (ICPCSI), September, 2017, pp. 2915-2919, IEEE.

Szakonyi, D. and Urpelainen, J. (2015). The Benefits of solar technology adoption for street vendors in Bihar. International Growth Centre-working paper, pp. 2-6.

Twidell, J. (2006). Weir Renewable energy resources. 2nd ed. London and New York: Taylor and Francis Group, pp. 1-4, 85-87.

Van Bommel, W. and Van den Beld, G. (2004). Lighting for work: a review of visual and biological effects. Lighting research \& technology, 36(4), 255-266.

Wadi, M., Shobole, A., Tur, M.R. and Baysal, M. (2018). Smart hybrid wind-solar street lighting system fuzzy based approach: Case study Istanbul-Turkey. In: 6th International Istanbul Smart Grids and Cities Congress and Fair (ICSG), April, 2018, pp. 71-75, IEEE. 
Zobaa, A. F. and Bansal, R. C. (2011). Handbook of renewable energy technology: World Scientific, pp. 4,189,205-210.

Cite this article as:

Bello-Yusuf S. and Bello A., 2020. Energy Sustainability Paradox: Exploring the Challenges and Opportunities of Solar LED Street Lights in Sokoto, Nigeria. Nigerian Journal of Environmental Sciences and Technology, 4(1), pp. 260-271. https://doi.org/10.36263/nijest.2020.02.0204 